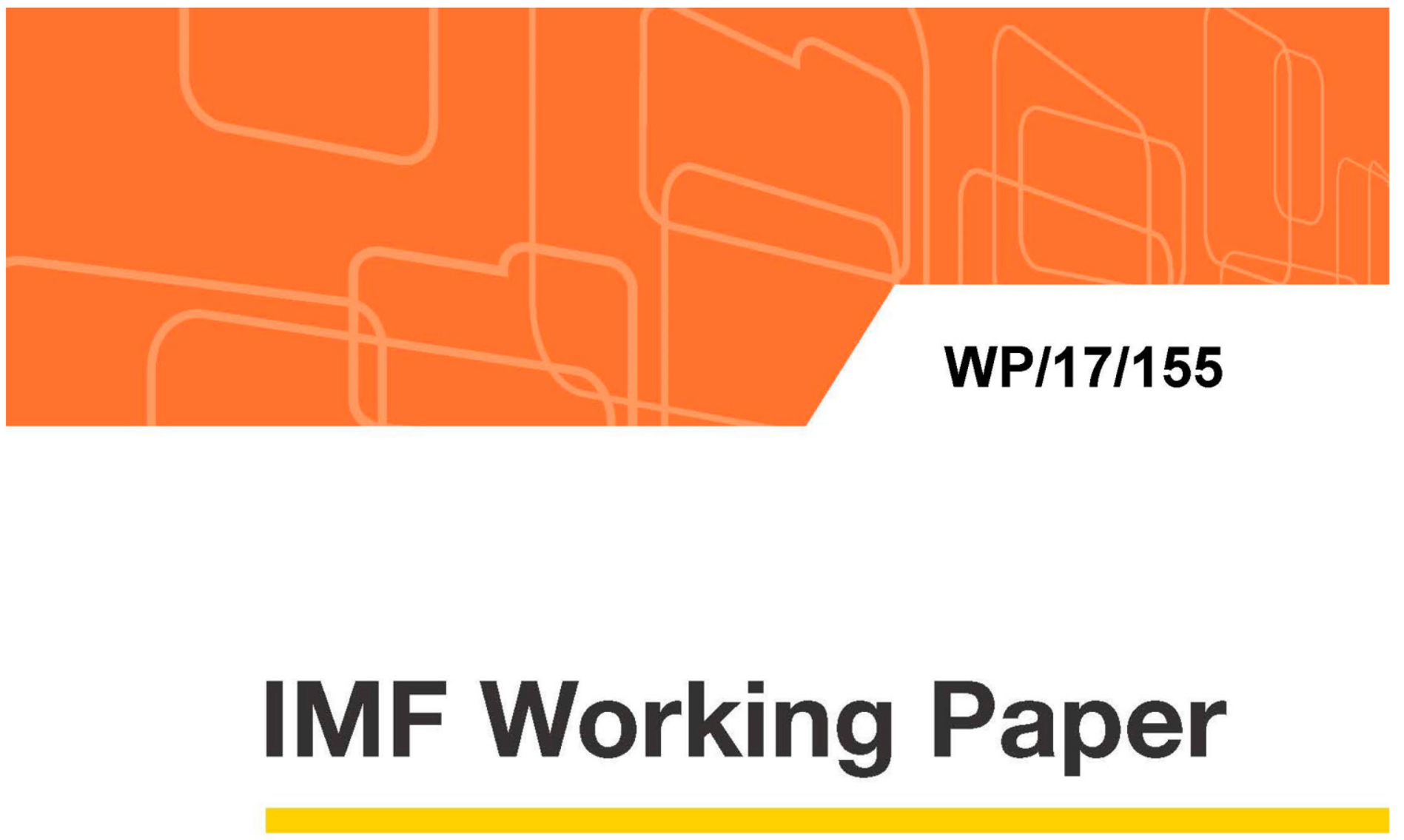

\title{
IMF Lending in an Interconnected World
}

\author{
Jean-Guillaume Poulain and Julien Reynaud
}

IMF Working Papers describe research in progress by the author(s) and are published to elicit comments and to encourage debate. The views expressed in IMF Working Papers are those of the author(s) and do not necessarily represent the views of the IMF, its Executive Board, or IMF management. 


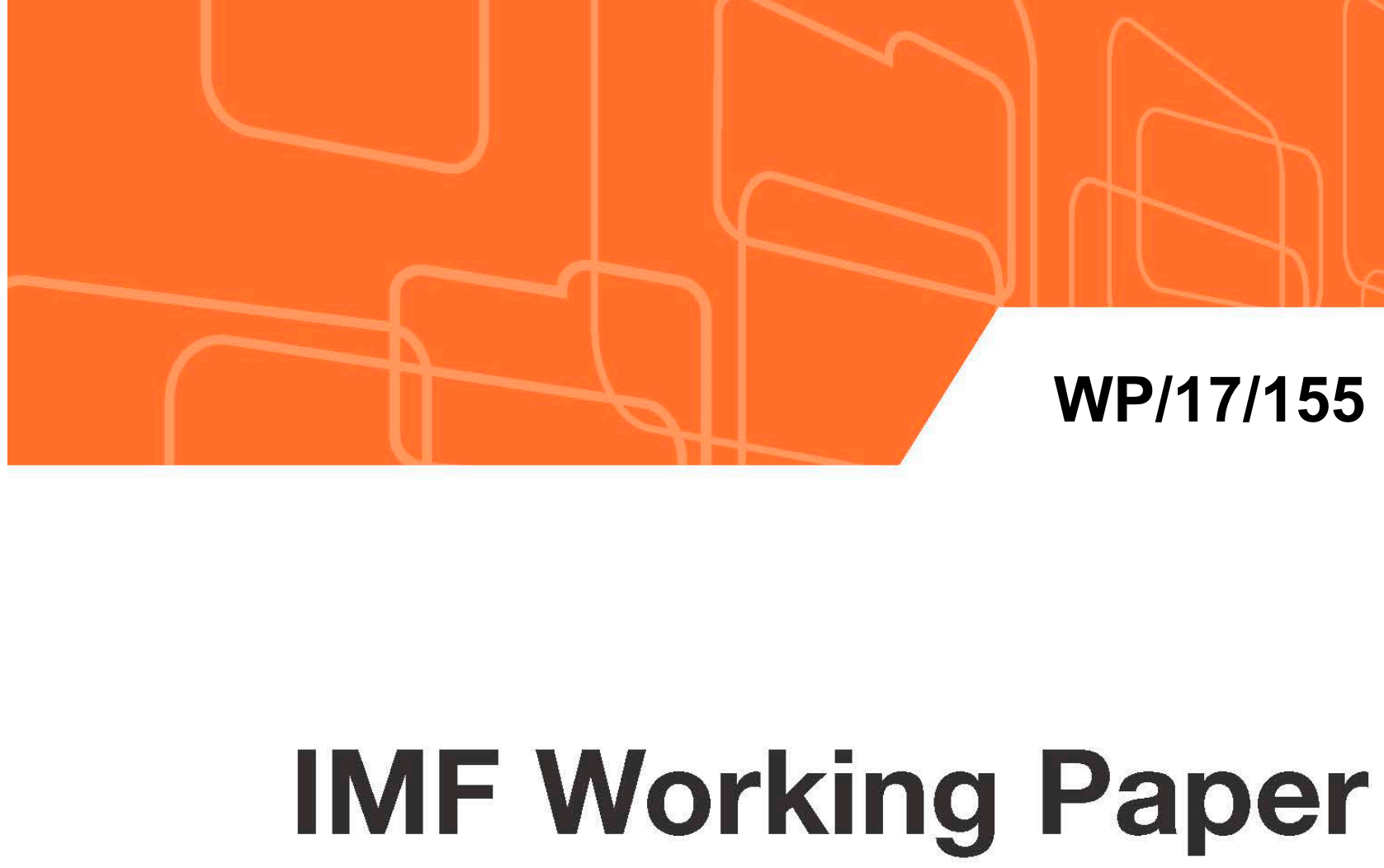

\title{
IMF Lending in an Interconnected World
}

\author{
Jean-Guillaume Poulain and Julien Reynaud
}

IMF Working Papers describe research in progress by the author(s) and are published to elicit comments and to encourage debate. The views expressed in IMF Working Papers are those of the author(s) and do not necessarily represent the views of the IMF, its Executive Board, or IMF management.

I N T E R N A T I O N A L M O N E T A R Y F U N D 


\title{
IMF Working Paper
}

Finance Department

\section{IMF Lending in an Interconnected World Prepared by Jean-Guillaume Poulain and Julien Reynaud ${ }^{1}$}

Authorized for distribution by Donal McGettigan and Catherine Pattillo

June 2017

IMF Working Papers describe research in progress by the author(s) and are published to elicit comments and to encourage debate. The views expressed in IMF Working Papers are those of the author(s) and do not necessarily represent the views of the IMF, its Executive Board, or IMF management.

\begin{abstract}
We analyze the determinants of IMF lending since the early nineties, a period during which the roles of financial cycles and interconnectedness as amplifiers and transmitters of economic crises have gained prominence. First, we show that the global financial cycle is an important driver of IMF lending cycles. Second, using a panel of 91 advanced, emerging, and frontier economies over 1992-2014, we show that global factors and interconnectedness, as proxied by a countries' potential exposure to economic spillovers from trade partners, together with more traditional idiosyncratic factors, have a significant impact on the probability that a member country obtains financial assistance from the IMF. Our results are robust to various robustness checks. The approach presented in this paper can be used to assess future demand for IMF financial assistance.

JEL Classification Numbers: F00, F33, F34, F42
\end{abstract}

Keywords: IMF lending, interconnectedness, global financial cycle, spillovers

Author's E-Mail Address: jpoulain@,imf.org, jreynaud@,imf.org

\footnotetext{
${ }^{1}$ The authors would like to thank Diana Mikhail for outstanding research assistance. They would also like to thank Pragyan Deb, Johannes Eugster, Mai Farid, Fei Liu, Donal McGettigan, Wes McGrew, Natalia Stetsenko, and Julien Vauday as well as participants to an IMF/FIN seminar for their useful comments and suggestions.
} 


\section{Contents}

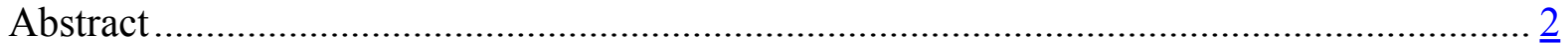

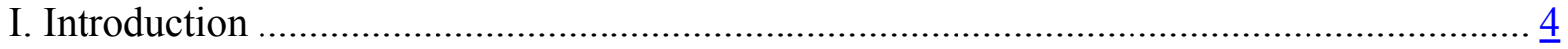

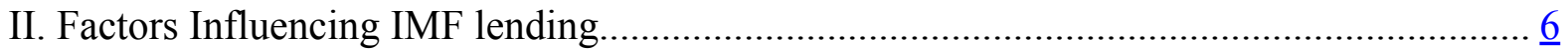

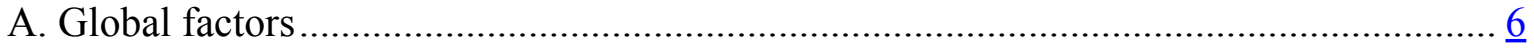

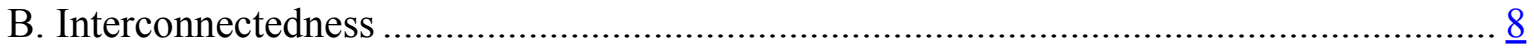

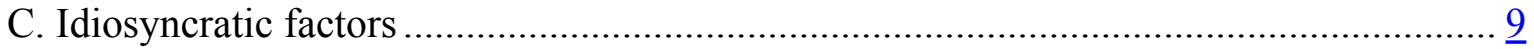

III. The Analytical Framework ……………………………………………………. 10

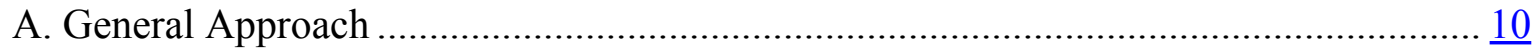

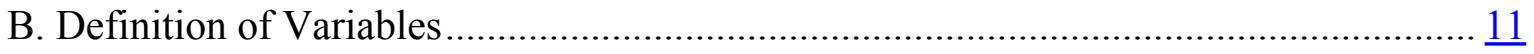

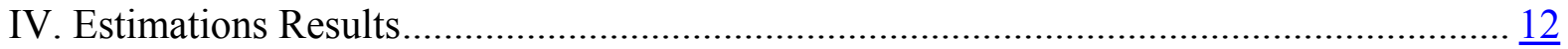

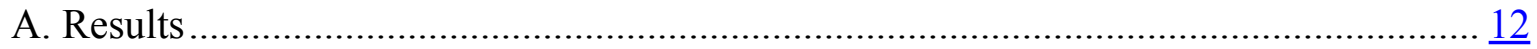

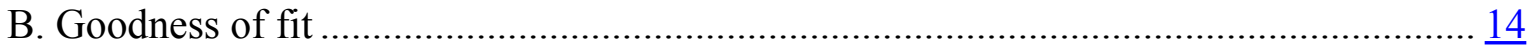

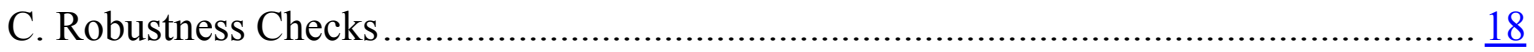

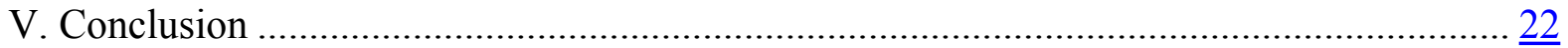

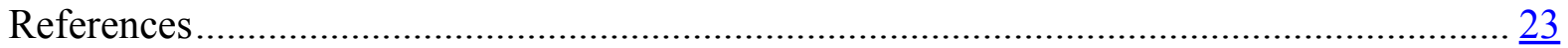

Annex I - Long term relationship between GRA credit outstanding and the VIX ................. $\underline{26}$

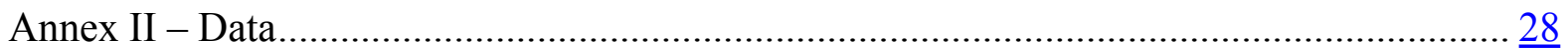

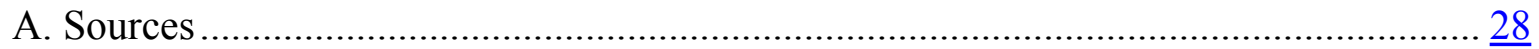

B. Interconnectedness indicators' panel summary statistics............................................. 29

C. Countries in the sample .................................................................................... $\underline{30}$ 


\section{INTRODUCTION}

The IMF plays an important role in safeguarding global economic and financial stability. Per Article I (v) of its Articles of Agreement, one of its key purposes is to "give confidence to members by making the general resources of the Fund temporarily available to them under adequate safeguards, thus providing them with opportunity to correct maladjustments in their balance of payments without resorting to measures destructive of national or international prosperity." Therefore, under the right set of conditions, the interests of a requesting country and the IMF can be aligned. Agreeing on a Fund-supported program and defining the size of associated financing are complex processes where demand factors - primarily driven by the size of countries' Balance of Payment (BoP) needs- and supply factors - the IMF's role in the international monetary system, and its lending and policy framework, including access limits, conditionality, exceptional access policy, financing assurances- are often closely intertwined. Ultimately, reaching an agreement depends on the requesting country's willingness to adjust its macroeconomic policies to return to a stable equilibrium.

While the original focus of the Fund was merely on current account disequilibrium, the term BoP is broad enough and has allowed the Fund to remain relevant in a more financially globalized world. Since the mid-1990s, one major development has been the dramatic acceleration of financial integration, along with continued trade integration. Globalization has brought many benefits to the global economy, but it has also increased systemic risk, giving rise to larger shocks that can propagate faster. In particular, the 2008/09 global financial crisis highlighted the impact that the complexity of systems and their interconnectedness can have on the global economy. It has highlighted (i) the potential negative impact of rapid credit growth, rising financial interconnectedness, and financial deepening on economic stability; and (ii) the potential for contagion through spillovers across national borders.

These developments have been acknowledged by the IMF and have impacted two of its main activities. First, the Fund revamped its lending toolkit in 2009, including by creating new precautionary instruments and increasing access levels to its resources ${ }^{2}$. Second, recognizing the increasingly important international dimensions of surveillance and of cross-country spillovers, the Fund adopted an integrated surveillance decision in 2012 to better integrate its bilateral and multilateral surveillance 3 . Importantly, in several programs in the wake of the global financial crisis, the Fund frontloaded disbursements to mitigate contagion from crisis countries ${ }^{4}$. The latter suggests that beyond country-specific factors, global factors and spillovers are relevant for the Fund's decision to grant financing to a country.

Predicting IMF lending is therefore by nature a difficult endeavor, which is further complicated by the evolving nature of crises and structure of the global economy. From a

\footnotetext{
${ }^{2}$ See IMF (2009)

${ }^{3}$ See IMF (2012)

${ }^{4}$ See IMF (2011)
} 
purely analytical point of view, distinguishing between supply of and demand for IMF resources is also an unresolved dilemma for researchers. In general, studies analyzing IMF lending tend to focus on domestic economic fundamentals, as well as political and geopolitical factors. In this paper, we explicitly take account of interconnections between countries and show that they are significant in helping explain new financing arrangements. We also show that both country-specific and global financial variables have explanatory power, with the latter suggesting that the global financial cycle has a significant impact on IMF lending cycles. Our analysis is based on a panel data set of 91 member countries that are potential users of Fund resources from the General Resource Account (GRA) over 19922014. ${ }^{5}$ The broad sample of countries encompasses not only emerging and frontier economies, but also advanced economies, as the crisis has disproved the notion that Fund support may be needed only in the former, as was thought in the most recent decades.

The paper is organized as follows. In Section II, we discuss patterns and cycles of IMF lending, including a brief review of the literature on the determinants of Fund lending. We also define interconnectedness and show evidence of a long-term relationship between global risk aversion and the Fund's GRA credit outstanding. In Section III, we describe our analytical framework to model the determinants of the use of Fund resources using countryspecific and global variables. Section IV presents the results. Section V concludes.

\footnotetext{
${ }^{5}$ The paper focuses on the non-concessional General Resource Account (GRA) lending and does not discuss the size of the Poverty Reduction and Growth Trust (PRGT)

${ }^{6}$ The variables discussed in the paper are not the actual criteria that the Fund uses when deciding on approving a member's access to its resources. Rather, the paper explores the possible indicators of probability of country's requiring to the Fund's financing. Fund policies governing the access to Fund financing include strength of the member's program, member's balance of payments need and capacity to repay the Fund.
} 


\section{FACTORS INFLUENCING IMF LENDING}

Over time, IMF lending cycles have become longer and larger. This increased use of Fund resources reflected the larger scale of financing in many cases, often associated with high sovereign debt and deficits as well as banking or financial sector weaknesses. As a result, the Fund has increasingly been called upon to provide financing on a larger scale in relation to members' GDP. For instance, for the top ten borrowers, average Fund credit outstanding amounted to over 7 percent of a country's GDP in 2012, compared to 4 percent in 1998 (Figures 1 and 2).
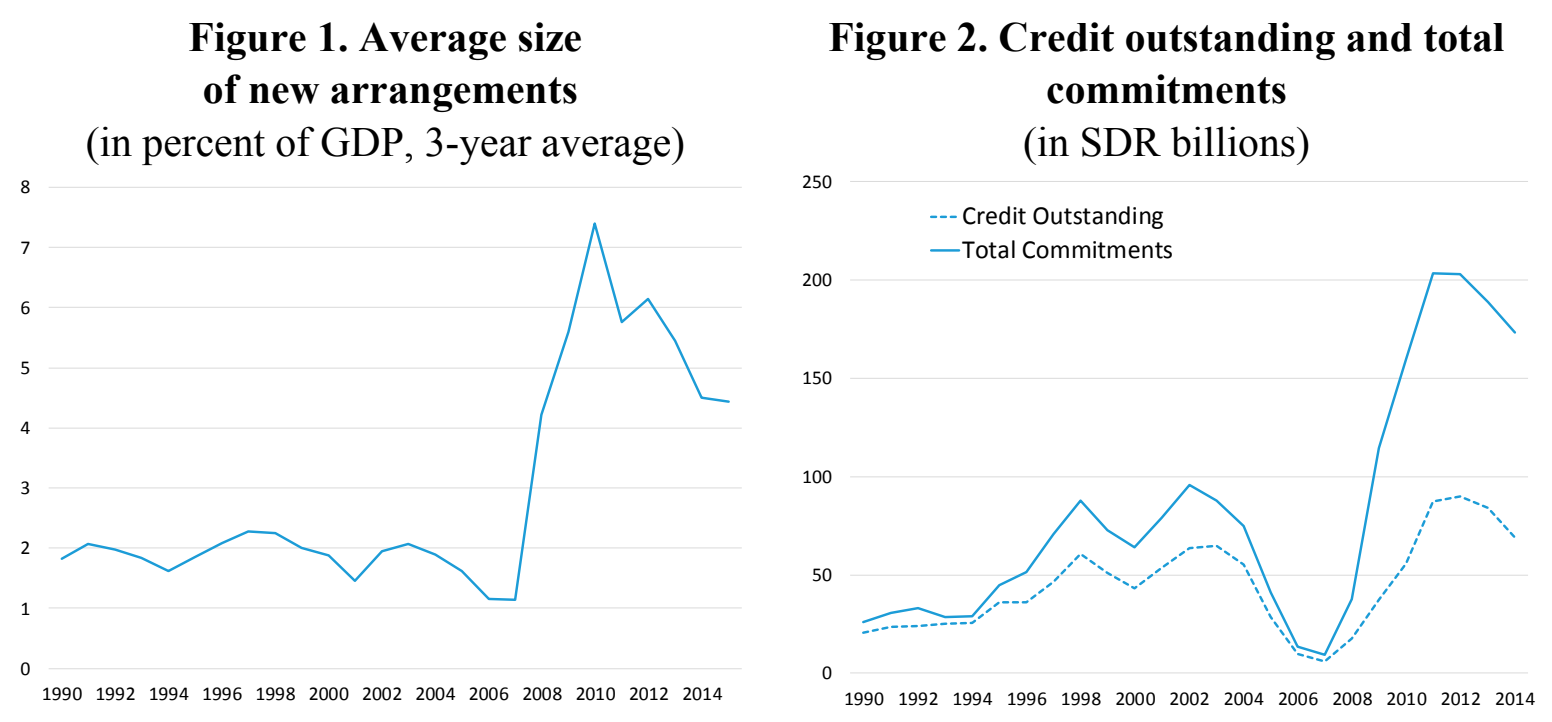

\section{A. Global factors}

Rey (2015) shows evidence supporting the existence of a global financial cycle in capital flows, asset prices, and in credit growth. This global cycle commoves closely with the VIX, a proxy for global risk aversion. ${ }^{7}$ For many economies, this global cycle can lead to excessive credit growth in boom times and excessive retrenchment in bad times. If the patterns of capital inflows and outflows follow a global financial cycle which is synchronized with fluctuations in world market risk aversion and uncertainty, one would expect an increase in the VIX index to impact IMF lending as they trigger large balance of payments needs for countries that built vulnerabilities up during a long period of easy global financial conditions. We test this hypothesis by adopting an ARDL approach, as in Pesaran and Shin (1999), to test level relation of the VIX and IMF lending, using quarterly data from 1990 Q4 to 2014 Q4. Using the correct t-statistic threshold provided by Pesaran et al. (2001), we show that the

\footnotetext{
${ }^{7}$ The VIX is the ticker for the CBOE volatility index, which shows the market's expectation of 30-day volatility. It is constructed using the implied volatilities on a wide range of S\&P500 index options. This volatility is meant to be forward looking, is calculated from both calls and puts, and is a widely used measure of market risk, often referred to as the "investor fear gauge."
} 
VIX is statistically significant at the 5 percent level. As a robustness test, we add global GDP as a third variable (see Annex I). Results show that although there is no level relationship between GRA credit outstanding and GDP, GDP variations are useful to explain short term dynamics, and most importantly, the level relationship between GRA and VIX still holds.

\section{Figure 3. GRA Credit Outstanding Actual and Fitted by ARDL Model with VIX (in SDR millions)}

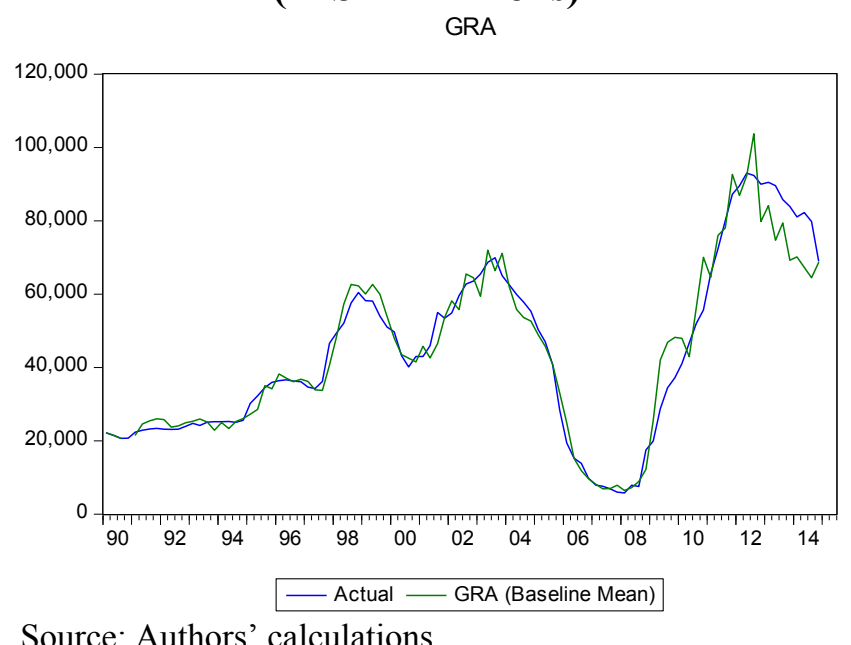

The role of other global factors has been identified in some past studies. Using panel data over the period 1970-2004, Elekdag (2006) showed that oil prices, world interest rates, and the global business cycle all affect the probability of requesting Fund financial assistance. Cerutti (2007) also finds global real GDP to be significant, but not anymore after the Mexican crisis in 1994. Previously, only Bird and Rowlands (2002) and Conway (1994) included global economic factors - in both cases through a measure of world interest rates. Bird and Rowland (2010) make a convincing case for the significance of world interest rates on IMF lending: "if borrowing from international capital markets is a preferred alternative to borrowing from the IMF then, more generally, aggregate IMF lending would be expected to depend negatively on the access that emerging or developing countries have to such markets. As the scarcity of international capital may be expected to be reflected positively by global interest rates, it follows that aggregate IMF lending should tend to rise alongside a rise in global interest rates. Similarly, countries with large amounts of external debt may find it more difficult to borrow and may therefore be pushed towards the Fund in circumstances where they would otherwise have built up their indebtedness to private capital markets." 


\section{B. Interconnectedness}

Over time, larger cross-border capital flows and increased trade and financial inter-linkages appear to have raised the size of potential financing needs ${ }^{8}$ and the scope for contagion across countries. ${ }^{9}$ Higher interconnectedness could pose greater systemic risk and cause quicker propagation of shocks. Minoiu and others (2013) show evidence that higher levels of a country's interconnectedness are associated with a higher probability of crisis. Furthermore, changes in neighboring countries' interconnectedness have a bearing on the likelihood of crisis, through spillover effects and potential contagion. Given these factors, even small shocks can quickly snowball, and increase the likelihood of crises. Spillovers can be especially severe if adverse shocks originate in countries with large and globally interconnected trade and financial markets.

Accounting for interconnectedness relates to a country's linkages with others, or in other words its importance and its place in the global economy. Interconnectedness has been mainly used as a mapping device to identify vulnerabilities emanating from exposures to connected countries and neighbors. Such exposures are usually measured by bilateral financial and trade flows, and distance. In statistical terms, for the purpose of our analysis, this refers to potential analysis developed by Reynaud and Vauday (2007) who use such concept in order to measure the geopolitical potential of a country based on its geographical location. The concept is inspired by Harris' (1954) influential market-potential function, which states that the demand for goods produced in a location is the sum of purchasing power in other locations, weighted by transport costs. The concept was later strengthened by Fujita, Krugman, and Venables (1999) stating that nominal wages are higher near concentrations of consumer and industrial demand (Hanson, 2005). In this paper, we adapt Reynaud and Vauday's (2009) analysis to catch how a country's economic situation could be affected by its partners' economic situations. Formally, the statistical analysis is computed as follow for each explanatory variable:

$$
p x_{i, t}=\sum_{j \neq i}^{n-i} \frac{x_{j, t}}{\varphi_{j, i, t}}
$$

where $p x_{i, t}$ is the potential measure a country $i$ 's exposure to spillovers/interconnectedness for a set of explanatory variable $x, x_{j, t}$ is the partner country $j$ explanatory variable $x$ and $\varphi_{j, i, t}$ the measure of interconnectedness between country $i$ and $j$. Interconnectedness can be defined using different measures in our analysis: (i) by trade flows ( $\mathrm{X}$ for exports and $\mathrm{M}$ for imports) among trade partners for our benchmark model. In this case, $\varphi_{j, i, t}$ is defined as $1 /\left(M_{j, i, t}+X_{j, i, t}\right)$. For illustrative purpose, we also use geographical distance (D) between partners. In this case, $\varphi_{j, i, t}$ is defined as $D_{j, i, t}$. Another important proxy for interconnectedness

\footnotetext{
${ }^{8}$ Gross external financing needs are estimated to have more than tripled since 1990.

${ }^{9}$ See IMF (2010a) and IMF (2011)
} 
are financial flows. However, remains scarce, mostly concentrated among advanced economies, and limit too drastically the sample to present meaningful estimations.

\section{Idiosyncratic factors}

A review of variables used in the literature suggests that results differ among studies, in part because the drivers of IMF lending cycles and the nature of crises evolve over time (for a good review of the literature, see Sturm et al., 2005). As financial markets developed, many economies were able to finance their external obligations through private financial markets and without the need for IMF resources. Most importantly, there is certainly a tradeoff between the constraint linked with IMF conditionality and the cost of funding BoP needs through private financial markets (Poulain and Reynaud, forthcoming). But reliance on private financial market also created additional vulnerabilities - aside from the ones related to relatively higher cost of funding - and the nature of crises shifted over time from pure current account crises to capital account crises. Furthermore, the samples of countries, periods of coverage, and types of IMF arrangements considered vary across studies. Most of the literature focuses on economic variables, but also institutional, political, and geopolitical variables.

\section{Economic variables}

Sturm et al. (2005) conducted an extreme bounds analysis on a panel of 118 countries over 1971-2000 to assess the determinants of Fund financing. Their comprehensive analysis suggests that real GDP growth, reserve coverage (in months of imports), current account deficit, GDP per capita, and persistence of IMF involvement ${ }^{10}$ are significant determinants. Elekdag (2006) concluded that the most important country-specific factors include real GDP growth, the depreciation of its currency vis-à-vis the U.S. dollar, its international reserve coverage, and whether it is an energy exporter. Ghosh et al. (2007) estimate that the more likely a country is to sign an IMF arrangement, the lower the reserve coverage, the higher total external debt and change in current account balance, and inflation rate. Their review of the literature also suggests that reserve coverage and GNP per capita are often found to be statistically significant, while results are mixed for current account deficit, real GDP growth, external debt service, and fiscal deficit among others. The example of the current account deficit is interesting: a country experiencing a very sharp recession and associated contraction of imports can be in a situation where its current account deficit has considerably improved - and even turned positive, yet still experience a BoP need that calls for Fund's support.

\section{Political and institutional variables}

Like Sturm et al. (2005), Ghosh et al. (2007) also underscore that most political variables that have been put forward in previous studies on IMF involvement do not robustly explain IMF

\footnotetext{
${ }^{10}$ Five year moving average of dummy indicating whether a country was under an arrangement.
} 
agreements. Government stability and bureaucratic quality are among variables that are found to be robust. This is consistent with the idea that the use of Fund resources is generally tied to a Fund-supported program entail an engagement with a government over about an average 3-year period, with the need to implement policies in complex environments to restore equilibrium.

\section{Other factors}

A niche in the literature on IMF lending has focused on the international allocation of aid. The underlying hypothesis is that multilateral lending could be influenced by bilateral political considerations. Among others, Dreher and Sturm (2012) make the link between UN security council seats and IMF and World bank lending. Separately, Reynaud and Vauday (2009) demonstrated that countries' geopolitical importance is a robust determinant of IMF lending. Developing a geopolitical index and using principal component analysis, they also found that countries' geopolitical potential, proxied as the geographic location (distance) of the recipient country to geopolitically important countries, plays an important role in IMF lending.

\section{The Analytical Framework}

\section{A. General Approach}

The model can be seen as reduced-form estimates of the decision by a member to request a GRA arrangement and by the Fund to agree to such a request. Past studies trying to disentangle demand and supply factors have been criticized. ${ }^{11}$ Consequently, the IMF lending model is different from typical market mechanisms where supply and demand are balanced by variation in prices, not least because the Fund's rate of charge is exogenously set. Our analysis focuses therefore on joint determinants of programs.

We estimate a binary response model for panel data for 91 advanced and emerging market economies over the period 1992-2014 to gauge the effects of various economic and financial variables on the likelihood that a member obtains new GRA financing. The general specification for these models is given by:

\footnotetext{
${ }^{11}$ Bird and Rowlands (2010): "the classification of demand- and supply-side factors is complex and varies over time, as changes within the Fund on the supply side may in turn influence or facilitate the demand for IMF resources. For example, the Fund may reform the range, nature and lending limits of the facilities under which member countries may borrow. However, many of these supply-side changes themselves reflect the prevailing economic conditions and have been made in response to the latent demand for IMF resources, and they are sporadic and difficult to measure systematically."
} 
$\mathrm{Y}_{\text {it }}=1$ if a GRA arrangement is agreed upon

$\mathrm{Y}_{\mathrm{it}}=0$ otherwise

$\operatorname{Pr}\left(\mathrm{Y}_{\mathrm{it}}=1 \mid \mathrm{X}_{i t-1}, \mathrm{Z}_{\mathrm{t},} c_{i}\right)=\mathrm{P}\left(\mathrm{X}^{\prime}{ }_{i t-1} \beta+\mathrm{Z}_{\mathrm{t}} \mathrm{\delta}+c_{i}\right)$ for $\mathrm{i}=1, \ldots, \mathrm{n}$ panels where $\mathrm{t}=1, \ldots, \mathrm{T}$,

where $\mathrm{P}()$ is a cumulative density function ${ }^{12}, Y$ is the observed outcome, $\mathrm{X}_{i t}$ is the vector of country-specific variables, $Z_{\mathrm{t}}$ the vector of global variables, $\beta$ and $\delta$ the vectors of coefficients associated with $\mathrm{X}_{i t}$ and $\mathrm{Z}_{\mathrm{t}}$, and $c_{i}$ are unobserved individual effects. The countryspecific variables are lagged to avoid endogeneity and simultaneity problems. The explanatory variables used are detailed in the next subsection.

We use the random effects estimator for the benchmark specification: as underscored by Elekdag (2006), the conditional fixed effects estimator would drop countries from the sample that have never had an IMF arrangement, thus introducing a serious selection bias. Indeed, this estimation procedure assesses how the independent variables influence the probability of switching to an IMF arrangement. Since countries that have never had an IMF arrangement do not switch, they do not provide any information towards the optimization of the likelihood function and are thus dropped. In our case, this selection bias would have considerably reduced the sample of countries from 91 to 41. Furthermore, the interconnectedness, GDP per capita, size, and government stability variables, as well as the variable for repeated use of Fund resources, are good proxies for institutional strength and capture, to a very large extent, variations across countries. Finally, we performed a Hausman test and could not reject the null hypothesis that the unobserved individual level effects are uncorrelated with the other covariates. This favors the use of the random-effects estimator over the fixed-effects estimator.

\section{B. Definition of Variables}

Based on the considerations discussed in the previous section, we use the following set of country-specific and global variables in accordance with the related literature.

Global variables. We have three global variables: the VIX, as a measure of risk aversion, the variation of the 3-month U.S. interest rate, and finally a measure of oil prices ${ }^{13}$.

Country-specific variables. A key driver of whether a country requests and obtains financial assistance is a BoP need (whether it is an actual or prospective, potential need). We use external financing needs (EFNs) as a proxy. EFNs encompass current account deficit and a

\footnotetext{
12 The logit model uses the logistic distribution, given by $\mathrm{P}(\mathrm{z})=\frac{1}{1+\exp (-z)}$, while the probit model uses the standard normal distribution. Our benchmark model uses the logistic distribution. Using the standard normal distribution (probit model) gives very similar results, as discussed in Section IV.C. on robustness checks. ${ }^{13}$ Following Elekdag (2006), we use deviations from the trend rather than the growth rate of oil prices, to capture persistence. Specifically, we use the difference between oil prices and their past 5-year average.
} 
measure of reserve coverage and are calculated following IMF's standards (2010b): first, gross financing needs are estimated as the sum of current account deficits net of grants, medium- and long-term debt amortization, arrears repayments, and reserve accumulation. EFNs are then calculated by adjusting gross financing needs to include short-term debt, but to exclude reserve accumulation by countries with reserves exceeding short-term debt, and to also exclude countries with negative gross financing needs. Historically, Fund commitments peaked at about 12 percent of EFNs in 1998, 2002, and during the global crisis. The other country-specific variables that enter our benchmark model are the credit-to-GDP gap ${ }^{14}$, real GDP growth, a measure of whether a country had a program in the recent past ${ }^{15}$, and government stability ${ }^{16}$. We also control for levels of development (GDP per capita), size (GDP), and the variation of bilateral nominal exchange rate against the US dollar (See Annex II.A-C. for description of the data, sources, and the sample).

\section{ESTIMATIONS RESUlts}

Since our focus is on interconnectedness, we present two models: an extended model, where interconnectedness measures are calculated for each country-specific variables; and a parsimonious model, where interconnectedness is proxied by a vector of all country-specific interconnectedness variables using principal component analysis (PCA). While this variable is somehow difficult to interpret, it represents macro-economic threats from partner countries. When spillovers become negative, the probability of a recipient of IMF lending increases. Such an approach allows to limit the number of variables in the estimation, possible collinearity and provides a handy single variable that proxies macroeconomic interconnectedness. Our results, when measuring the importance of spillovers, are in line with related studies gauging interconnectedness, for example in view of matching the top 25 systemically important trade and financial jurisdictions (Errico and Massara, 2011).

\section{A. Results}

Unadjusted logit coefficients are not easily interpretable. Our model is indeed non-linear, as the logistic distribution function is fitted so that the probability of a GRA arrangement is constrained to the range $[0,1]$. Therefore, in the following tables we report average marginal effects, i.e. the effect of one-unit increases in the independent variables on the probability (in percent) of a new arrangement evaluated at the means of the data.

\footnotetext{
${ }^{14}$ Measured as the deviation of credit-to-GDP from its 6-year average.

${ }^{15} 5$-year average of a dummy that takes the value 1 when a member has an active IMF arrangement.

${ }^{16}$ We use the ICRG Government Stability indicator.
} 
The results from the benchmark parsimonious model are reproduced in Table 1 below, first column. All global variables, except the oil price, are significant. All the coefficients also have the expected sign. The probability of having a new IMF arrangement is positively related to the VIX and short-term US interest rates, consistent with the idea that higher volatility and tighter financial condition can trigger BoP problems in countries that built up vulnerabilities. Similarly, the probability of having a new IMF arrangement also increases with higher external financing needs, lower GDP growth, and lower GDP per capita. Whether a country had an IMF arrangement in the past 5 years also has a positive impact on its likelihood to require a new arrangement. Interestingly, the probability also increases with lower government stability. Related studies emphasize the fact that the IMF tend to lend more to country with more stable governments, yet since political and economic and financial crises are usually closely linked, Fund lending sometimes coincides with episodes of higher government instability. Credit-to-GDP gap is also significant and with a positive sign: financial deepening brings significant benefits, but also increases the likelihood of crisis as it is often associated with periods of rapid credit growth. Finally, the interconnectedness PCA variable is significant and the marginal effect is relatively high, advocating for the fact that the results support the hypothesis that potential negative spillovers may have a positive impact on Fund lending probability.

The second column of Table 1 also reports the benchmark model including all interconnectedness measures for all country-specific variables. Results suggest that the probability of having an IMF program is higher when a country is more connected to countries with decreasing GDP growth, or to large economies. 
Table 1. Benchmark Models - Regression Results

\begin{tabular}{|c|c|c|}
\hline \multirow[b]{2}{*}{ Independent variables } & \multicolumn{2}{|c|}{ Models: } \\
\hline & Parsimonious & Extended \\
\hline \multicolumn{3}{|l|}{ Global variables } \\
\hline 3-month US rate (variation) & $0.012 *$ & $0.012 *$ \\
\hline VIX & $0.004 * * *$ & $0.004 * * *$ \\
\hline Oil price & -0.001 & -0.001 \\
\hline \multicolumn{3}{|l|}{ Country specific variables } \\
\hline Past program & $0.013 * * *$ & $0.012 * * *$ \\
\hline External Financing Needs & $0.074 * *$ & $0.063 * *$ \\
\hline Interconnectedness (trade) EFN & & 0.219 \\
\hline GDP growth & $-0.002 * *$ & $-0.002 *$ \\
\hline Interconnectedness (trade) GDP growth & & $-0.048 *$ \\
\hline GDP per capita & $-0.024 * * *$ & $-0.024 * * *$ \\
\hline Interconnectedness (trade) GDP per capita & & $-0.239 * *$ \\
\hline GDP & 0.009 & $0.011 * *$ \\
\hline Interconnectedness (trade) GDP & & $0.432 * *$ \\
\hline Credit gap & $0.001 * *$ & $0.001 * *$ \\
\hline Interconnectedness (trade) Credit gap & & 0.031 \\
\hline Exchange rate variation & -0.033 & -0.037 \\
\hline Interconnectedness (trade) Exchange rate variation & & -0.546 \\
\hline Government Stability & $-0.012 * * *$ & $-0.011 * * *$ \\
\hline Interconnectedness (trade) Government stability & & -0.087 \\
\hline Overall interconnectedness & $-0.040 * *$ & \\
\hline Pseudo R2 (M\&Z) & 0.338 & 0.643 \\
\hline Observations & 1,630 & 1,630 \\
\hline Countries & 91 & 91 \\
\hline GRA Arrangements & 106 & 106 \\
\hline Wald test & $84.1 * * *$ & $84.6 * * *$ \\
\hline Log. Likelyhood & -315.5 & -310.3 \\
\hline
\end{tabular}

\section{B. Goodness of fit}

We report McKelvey and Zavoina's pseudo R-squared for all the regressions, keeping in mind that pseudo R-squared have limited meaning for non-linear models. For logit and probit models, a better way to measure goodness of fit is through counting the events correctly predicted and assessing the percentage of type I and type II errors.

To determine which countries are flagged by the model as entering into an IMF arrangement in a given year, a threshold is chosen such that if a country has a predicted probability in any given year that is greater than the threshold, the country is assumed to have an arrangement in that year. The choice of the probability threshold is therefore central to the model predictions. A probability threshold that is too high could potentially yield projections for 
new commitments which are too low, and vice versa. There are two standard approaches in the literature:

- The first is to set the threshold to be equal to the frequency of all programs in the historical sample. In our case, this threshold is 6.5 percent. Table 2 shows that using this threshold, the model correctly predicts the precise year for two thirds of new programs.

- The second is to minimize the loss function of Type I and Type II errors. Depending on the purpose of the analysis, one may want to assign different weights to Type I and Type II errors. Figure 4 shows Type I and Type II errors for different thresholds, and Figure 5 computes the loss function with $2: 1,1: 1$, and 1:2 weights assigned to each type of errors. Table 2 below summarizes the in-sample performance of the benchmark parsimonious and extended models respectively, for the sample threshold and the threshold minimizing the loss function with the 1:1 ratio, which are 3.5 percent for the parsimonious model and 4.5 percent for the extended model.

Overall performance of the models is satisfying. For the parsimonious model, the percentage of good calls ${ }^{17}$ is 77 percent (Table $2 \mathrm{a}$ ). Interestingly, the extended model provides a better balance of good calls and correctly predicted programs, the latter statistic being as high as 76 percent, when the threshold is set at 6.5 percent (Table 2b). Minimizing the loss function with the 1:1 ratio shows that the models can correctly predict above 90 percent of programs.

Table 2a. Performance for different thresholds of the parsimonious benchmark model

Threshold $\quad 6.5 \%$

(frequency of programs in the sample)

\begin{tabular}{|c|c|c|c|c|}
\hline & \multirow{2}{*}{\multicolumn{2}{|c|}{ Realized }} & \multirow{3}{*}{ Total } \\
\hline & & & & \\
\hline & & 1 & 0 & \\
\hline \multirow[t]{2}{*}{ Predicted } & 1 & 71 & 347 & 418 \\
\hline & 0 & 35 & 1177 & 1212 \\
\hline Total & & 106 & 1524 & 1630 \\
\hline
\end{tabular}

Good calls $\quad 77 \%$

Correctly predicted program $67 \%$

False positive $\quad 23 \%$

Missed new program $\quad 33 \%$
Threshold $\quad 3.5 \%$

(minimizes the loss function with 1:1 ratio)

\begin{tabular}{|lr|r|r|r|}
\cline { 3 - 5 } \multicolumn{1}{c|}{} & \multicolumn{2}{c|}{ Realized } & Total \\
\hline Predicted & 1 & \multicolumn{1}{c|}{0} & \\
\cline { 2 - 5 } & 1 & 96 & 558 & 654 \\
\hline Total & 10 & 966 & 976 \\
\hline
\end{tabular}

Good calls $\quad 65 \%$

Correctly predicted program $91 \%$

False positive $\quad 37 \%$

Missed new program $\quad 9 \%$

\footnotetext{
${ }^{17}$ The rate of good calls is the sum of (i) the number of programs predicted by the model that were realized and (ii) the number to non-program cases correctly estimated as such by the model, divided by total observations.
} 
Table $2 \mathrm{~b}$. Performance for different thresholds of the extended benchmark model

Threshold $\quad 6.5 \%$

(frequency of programs in the sample)

\begin{tabular}{|c|c|c|c|c|}
\hline & \multicolumn{2}{|c|}{ Realized } & \multirow[t]{2}{*}{ Total } \\
\hline & & 1 & 0 & \\
\hline \multirow[t]{2}{*}{ Predicted } & 1 & 81 & 382 & 463 \\
\hline & 0 & 25 & 1142 & 1167 \\
\hline Total & & 106 & 1524 & 1630 \\
\hline
\end{tabular}

Good calls $\quad 75 \%$

Correctly predicted program $76 \%$

False positive $25 \%$

Missed new program $\quad 24 \%$
Threshold $\quad 4.5 \%$

(minimizes the loss function with 1:1 ratio)

\begin{tabular}{|lr|r|r|r|}
\cline { 3 - 5 } \multicolumn{1}{c|}{} & \multicolumn{2}{c|}{ Realized } & Total \\
\hline Predicted & 1 & \multicolumn{1}{c|}{0} & \\
\cline { 3 - 5 } & 0 & 95 & 488 & 583 \\
\hline Total & 11 & 1036 & 1047 \\
\hline
\end{tabular}

$\begin{array}{ll}\text { Good calls } & 69 \% \\ \text { Correctly predicted program } & 90 \% \\ \text { False positive } & 32 \% \\ \text { Missed new program } & 10 \%\end{array}$

Figure 4. Type I and Type II errors of the parsimonious benchmark model

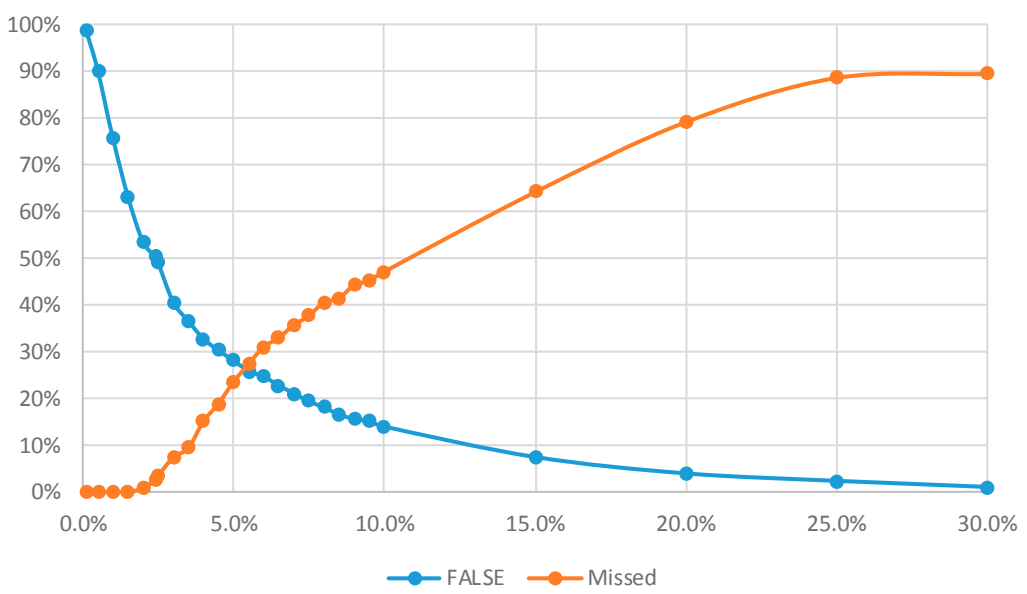

Figure 5. Determining thresholds for different weights of Type I and Type II errors for the parsimonious benchmark model

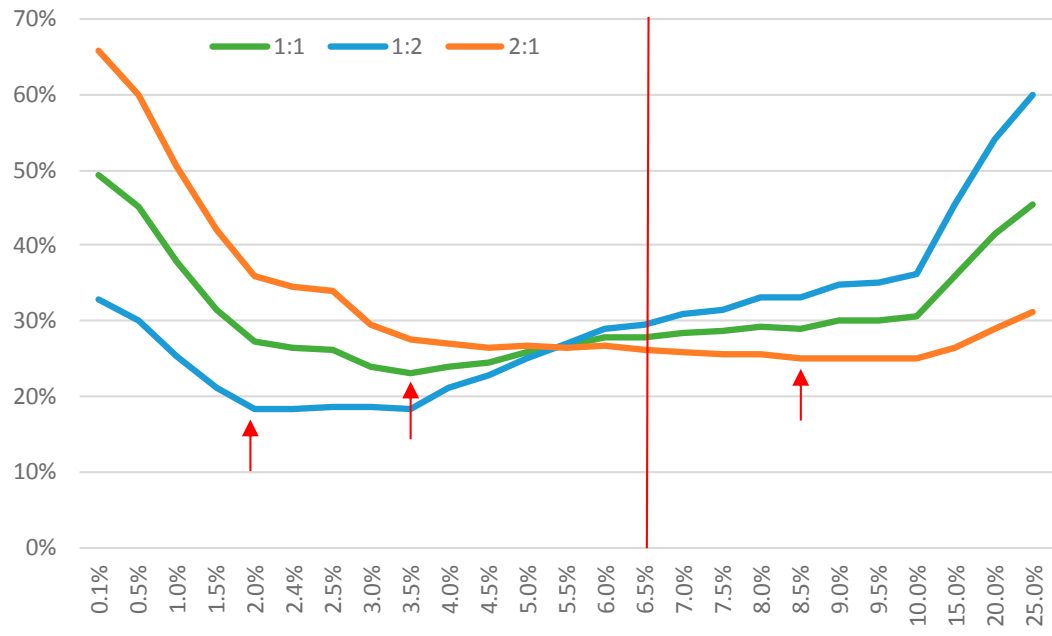


Note: the red vertical bar shows the frequency of events in the sample. The red arrows the thresholds obtained by minimizing the loss function.

Finally, another related question is whether a similar model can help predict whether a country is under an active GRA arrangement in a given year. The results shown in Table 3 suggest that this can be explained by a similar set of explanatory variables. Given that it is less difficult to predict whether a country is under a program rather than exactly when a new program starts, the goodness of fit is - not surprisingly - better for this model (see Tables 3 and 4).

Table 3. Likelihood that a country is under a GRA program - Regression results

\begin{tabular}{lc}
\hline Independent variables & Parsimonious model \\
\hline Global variables & $0.014^{* *}$ \\
3-month US rate (variation) & $0.004^{* * *}$ \\
VIX & $-0.001^{*}$ \\
Oil price & \\
Country specific variables & $0.020^{* * *}$ \\
Past program & $0.277^{* * *}$ \\
External Financing Needs & $-0.006^{* * *}$ \\
GDP growth & $-0.049^{* * *}$ \\
GDP per capita & $0.019^{*}$ \\
GDP & 0.001 \\
Credit gap & $-0.089^{*}$ \\
Exchange rate variation & $-0.016^{* * *}$ \\
Government Stability & $-0.069^{* *}$ \\
Overall interconnectedness & 0.407 \\
\hline Pseudo R2 (M\&Z) & 1,630 \\
Observations & 91 \\
Countries & 106 \\
GRA Arrangements & $129.1 * * *$ \\
Wald test & -451.8 \\
\hline Log. Likelyhood & \\
\hline
\end{tabular}

Notes: The table reports the marginal effects of the panel

logit estimations using random effects. A constant is estimated but not reported.

$* * *, * *$, and $*$ denote significance at the 1,5 , and 10 percent respectively. 


\section{Table 4. Performance historical frequency threshold}

Threshold $\quad 18.3 \%$

(frequency of programs in the sample)

\begin{tabular}{|lr|r|r|r|}
\cline { 2 - 4 } \multicolumn{1}{c|}{} & \multicolumn{2}{|c|}{ Realized } & Total \\
\cline { 2 - 4 } \multicolumn{1}{c|}{} & 1 & \multicolumn{1}{c|}{0} & \\
\hline Predicted & 150 & 128 & 278 \\
\cline { 3 - 5 } & 0 & 134 & 1218 & 1352 \\
\hline Total & 284 & 1346 & 1630 \\
\hline
\end{tabular}

$\begin{array}{ll}\text { Good calls } & 84 \% \\ \text { Correctly predicted program } & 53 \% \\ \text { False positive } & 10 \% \\ \text { Missed new program } & 47 \%\end{array}$

\section{Robustness Checks}

We perform a likelihood test comparing the pooled estimator with the panel estimator to confirm which specification is appropriate. Indeed, pooled estimation in nonlinear models leads to inconsistent parameter estimates if the assumed random effects model is appropriate, and vice versa. For the benchmark model, a random-effects specification is strongly supported since the likelihood test suggests that the correlation between two successive error terms for the same individual, $\rho$, is strongly significant. ${ }^{18}$

The results are robust to changes in the distribution function: Logit and panel Probit specifications give very similar results (Table 5). The results are also robust to a variation in the definition of the binary dependent variable (no reported here). If the latter is modified to exclude arrangements under the Flexible Credit Line (FCL) and the Precautionary and Liquidity Line (PLL), then a similar set of explanatory variable retains significance. Note that in this case, we cannot reject the null hypothesis that $\rho=0$, so the model performs better as a pooled logit. Given that a sample of programs focusing on IMF traditional lending instruments (SBA and EFF) is more homogeneous, it is not surprising that the pseudo Rsquare and, more generally, goodness of fit is better for this model compared to the benchmark model. The results are also robust to alternative measures of global volatility, such as the VIX squared, or the maximum quarterly average of the VIX in a given year.

Furthermore, since the main purpose of the paper is to test whether interconnectedness plays a role in Fund lending decisions, we test different measures of interconnectedness focusing on the country's economic importance (the nominator). Unfortunately, although there could be different ways to measure the channels of contagion (the denominator), data limitations

${ }^{18} \rho$ is the proportion of the total variance contributed by the panel-level variance component. When $\rho$ is zero, the panel-level variance component is unimportant, and the panel estimator is no different from the pooled estimator. 
render the use bilateral trade systematic. In particular, financial flows, portfolio as well as foreign direct investment, are important channels of spillovers. However, data is very scarce and would have limited the analysis to a much smaller sample of countries. Yet, there is a vast literature on the complementarity of trade and capital flows (see between others Antras and Caballero, 2009, and Jin, 2010). Theoretically, external debt is typically seen as being financed through the present value of future trade surpluses. We perform robustness checks testing different denominators such as exports (instead of the sum of exports and imports as it is often the case in trade economics) and distance. Results are similar when using exports only with the difference that the interconnectedness measure of the size variable (GDP) is not significant anymore while same measure of government stability turns significant. Another robustness check is performed to focus on the country-specific interconnectedness measures and gauge their significance against country-specific macro-variables. Table 6 shows the results of the regressions using only interconnectedness variables (for all the economic variables in the baseline model). The results suggest that GDP growth is the most important significant interconnectedness factor when it comes to assessing the probability of requiring an IMF arrangement.

Because IMF lending is sometimes associated with the occurrence of financial crises (banking and currency crises) in the recipient country or in partner countries through spillovers, we test two assumptions: (i) whether the occurrence of a financial crisis in a partner country affects the probability of requiring an IMF arrangement through spillovers; and (iii) whether introducing year dummies alter the results (although this is somehow a different exercise and introduce some bias in the estimation, we provide the results for information). 
Table 5. Robustness check - Different estimators

\begin{tabular}{|c|c|c|}
\hline \multirow[b]{2}{*}{ Independent variables } & \multicolumn{2}{|c|}{ Models: } \\
\hline & Cross section probit & Pooled logit \\
\hline \multicolumn{3}{|l|}{ Global variables } \\
\hline 3-month US rate (variation) & 0.011 & $0.235 * * *$ \\
\hline VIX & $0.004 * * *$ & $0.085 * * *$ \\
\hline Oil price & -0.001 & -0.009 \\
\hline \multicolumn{3}{|l|}{ Country specific variables } \\
\hline Past program & $0.012 * * *$ & $0.349 * * *$ \\
\hline $\begin{array}{l}\text { External Financing Needs } \\
\text { Interconnectedness (trade) EFN }\end{array}$ & $0.072 * *$ & $1.099 * *$ \\
\hline $\begin{array}{l}\text { GDP growth } \\
\text { Interconnectedness (trade) GDP }\end{array}$ & $-0.002 * *$ & $-0.041 *$ \\
\hline $\begin{array}{l}\text { GDP per capita } \\
\text { Interconnectedness (trade) GDP }\end{array}$ & $-0.023 * * *$ & $-0.402 * * *$ \\
\hline $\begin{array}{l}\text { GDP } \\
\text { Interconnectedness (trade) GDP }\end{array}$ & 0.005 & 0.091 \\
\hline $\begin{array}{l}\text { Credit gap } \\
\text { Interconnectedness (trade) Creo }\end{array}$ & $0.001 * *$ & $0.170 * *$ \\
\hline $\begin{array}{l}\text { Exchange rate variation } \\
\text { Interconnectedness (trade) Exch }\end{array}$ & ation & -0.928 \\
\hline $\begin{array}{l}\text { Government Stability } \\
\text { Interconnectedness (trade) Gov }\end{array}$ & $-0.013 * * *$ & $-0.262 * * *$ \\
\hline Overall interconnectedness & $-0.021 *$ & $-0.493 * *$ \\
\hline Pseudo R2 (M\&Z) & 0.308 & 0.189 \\
\hline Observations & 1,630 & 1,630 \\
\hline Countries & 91 & 91 \\
\hline GRA Arrangements & 106 & 106 \\
\hline Wald test & $85.5 * * *$ & \\
\hline LR test & & $148.2 * * *$ \\
\hline Log. Likelyhood & -313.1 & -318.1 \\
\hline
\end{tabular}


Table 6. Robustness check - Country-specific interconnectedness measures only

\begin{tabular}{lcc}
\hline & \multicolumn{2}{c}{ Models: } \\
\cline { 2 - 3 } Independent variables & Trade & Distance \\
\hline Past program & $0.015^{* * *}$ & $0.017^{* * *}$ \\
Interconnectedness EFN & $3.499^{* * *}$ & $7.787^{* *}$ \\
Interconnectedness GDP growth & $-0.069^{* * *}$ & $-0.135^{* *}$ \\
Interconnectedness GDP per capita & $-0.293^{* *}$ & $-0.610^{* *}$ \\
Interconnectedness GDP & $0.419^{* *}$ & -0.159 \\
Interconnectedness Credit gap & 0.037 & -0.068 \\
Interconnectedness Exchange rate variation & $-1.697^{*}$ & -1.663 \\
Interconnectedness Government stability & -0.314 & $-0.246^{* *}$ \\
\hline Pseudo R2 (M\&Z) & 0.625 & 0.195 \\
Observations & 1,630 & 1,630 \\
Countries & 91 & 91 \\
GRA Arrangements & 106 & 106 \\
Wald test & $33.8 * * *$ & $47.5^{* * *}$ \\
Log. Likelyhood & -335.4 & -335.9 \\
\hline
\end{tabular}

Notes: The table reports the marginal effects of the panel probit estimations using random effects and coefficient estimates for the pooled logit model. A constant is estimated but not reported. $* * *, * *$, and $*$ denote significance at the 1,5 , and 10 percent respectively.

Table 7. Robustness check - Financial crises and controlling for time dummies

\begin{tabular}{|c|c|c|}
\hline \multirow[b]{2}{*}{ Independent variables } & \multicolumn{2}{|c|}{ Models: } \\
\hline & With financial crisis & With time dummies \\
\hline \multicolumn{3}{|l|}{ Global variables } \\
\hline 3-month US rate (variation) & $0.012 *$ & 0.112 \\
\hline VIX & $0.004 * * *$ & -0.120 \\
\hline Oil price & -0.001 & 0.002 \\
\hline \multicolumn{3}{|l|}{ Country specific variables } \\
\hline Past program & $0.130 * * *$ & $0.015 * * *$ \\
\hline External Financing Needs & $0.072 * *$ & $0.064 * *$ \\
\hline GDP growth & $-0.002 * *$ & $-0.002 *$ \\
\hline GDP per capita & $-0.021 * * *$ & $-0.026 * * *$ \\
\hline GDP & $0.011 *$ & 0.008 \\
\hline Credit gap & $0.001 * *$ & $0.001 * *$ \\
\hline Exchange rate variation & -0.260 & -0.055 \\
\hline Government Stability & $-0.013 * * *$ & -0.007 \\
\hline Overall interconnectedness & $-0.058 * *$ & $-0.043 *$ \\
\hline Financial crisis interconnectedness & $0.001 * *$ & \\
\hline Pseudo R2 (M\&Z) & 0.428 & 0.430 \\
\hline Observations & 1,630 & 1,630 \\
\hline Countries & 91 & 91 \\
\hline GRA Arrangements & 106 & 106 \\
\hline Wald test & $84.2 * * *$ & $93.9 * * *$ \\
\hline Log. Likelyhood & -313.7 & -307.2 \\
\hline
\end{tabular}


Finally, we perform out-of-sample predictions for the years 2015 and 2016 using the parsimonious model. Our results confirm the predictive power of the model: 85 percent of the programs started in 2015 and 2016 are rightly predicted.

\section{Conclusion}

The IMF plays a major role in today's interconnected world, characterized by an increase in the frequency and the severity of economic and financial crises, and associated spillovers. Dampening the adverse effects of systemic risks is critical so that IMF members can reap the full benefits of globalization. A key lesson of the global financial crisis, underscored by the IMF's Independent Evaluation Office, was that, in order to fulfill this function effectively, the Fund needs to be adequately sized, with sufficient resources to play a catalytic role in assisting members to meet their actual, potential, or prospective financing needs, thereby supporting market confidence.

In this context, this paper sheds light on key factors affecting the probability that a country may require Fund financing. First, the paper shows that the global financial cycle, that commoves with measures of global uncertainty, is a major driver of the aggregate use of Fund resources since the 1990s. Second, using a panel of 91 countries over the period 19922014, the paper emphasizes the role of global factors and interconnectedness in explaining the likelihood that a member will require financial assistance from the Fund. The significance of different measures of interconnectedness suggests that the IMF may be taking into consideration potential spillovers when lending, consistent with its central role in the global financial safety net.

The model presented in this paper can be used to estimate countries' future financial assistance needs, both under the baseline and tail scenarios. While using baseline scenarios is useful to establish a watch list of potential new programs and their possible impact on the Fund's liquidity, using tail scenarios can be used to gauge the overall adequacy of Fund resources. Such estimates could be further refined by adopting a model-based approach to estimate the size of IMF arrangements, conditional on the prediction made by the logit model detailed in this paper. This ongoing work is the subject of a follow-up paper. 


\section{REFERENCES}

Antras, P., and Caballero, R., 2009. Trade and Capital Flows: A Financial Frictions Perspective. Journal of Political Economy, 2009, vol. 117, no. 4.

Bal Gündüz, Y., 2009. Estimating Demand for IMF Financing by Low-Income Countries in Response to Shocks. IMF Working paper WP/09/263.

Barro, R., and Lee, JW., 2005. IMF Programs: Who Is Chosen and What are the Effects? Journal of Monetary Economics, Vol. 52 (October), pp. 1245-69.

Bird, G., and Rowlands, D., 2001. IMF Lending: How Is It Affected by Economic, Political and Institutional Factors. Journal of Economic Policy Reform, Vol. 4, No. 3, pp. 243-70.

Bird, G., and Rowlands, D., 2002. The Pattern of IMF Lending: An Analysis of Prediction Failures. Journal of Economic Policy Reform, Vol. 5, No. 3, pp. 173-86.

Bird, G., and Rowlands, D., 2009. A disaggregated empirical analysis of the determinants of IMF arrangements: does one model fit all? Journal of International Development 21, 915-31

Bird, G., and Rowlands, D., 2010. The episodic and unpredictable nature of IMF Lending: an empirical Analysis. The world economy.

Bruno, V. and Shin, HS., 2013. Capital Flows and the Risk-taking channel of monetary policy. Working Paper Princeton University.

Cerutti, E., 2007. IMF drawing programs: participation determinants and forecasting. IMF Working paper $\mathrm{WP} / 07 / 152$

Conway, P., 1994. IMF lending programs: participation and impact. Journal of Development Economics 45, 365-391.

Dreher, A., and Sturm, JE., 2012. Do the IMF and the World Bank influence voting in the UN General Assembly? Public Choice 151: 363.

Errico, L., and Massara, A., 2011. Assessing Systemic Trade InterconnectednessAn Empirical Approach. IMF Working Paper No. 11/214.

Elekdağ, S., 2006. How Does the Global Economic Environment Influence the Demand for IMF Resource? IMF Working Paper No. 06/239 
Forbes, K., and Warnock, F., 2012. Capital Flow Waves: Surges, Stops, Flight and Retrenchment. Journal of International Economics 88(2): 235-251.

Gourinchas, P.-O. and Obstfeld, M., 2012. Stories of the Twentieth Century for the Twenty-First. American Economic Journal: Macroeconomics, 4(1), 226-65.

Gosh A., Goretti, M., Joshi, B., Thomas, A., and Zalduendo, J., 2008. Modeling aggregate use of fund resources - analytical approaches and medium-term projections. IMF Staff Papers, Vol. 55, No. 1.

Independent Evaluation Office of the IMF, 2014, IMF Response to the Financial and Economic Crisis, October 2014

International Monetary Fund, (2009) GRA lending toolkit and conditionality - Reform proposals, March 2009 (2010a) Understanding Financial Interconnectedness, October 2010. (2010b) Fourteenth General Review of Quotas - The Size of the Fund: Initial Considerations, March 2010

(2011a), Analytics of systemic crises and the role of global financial safety nets, June 2011

(2011b), Mapping Cross-Border Financial Linkages: A Supporting Case for Global Financial Safety Nets, June 2011

(2012), Modernizing the Legal Framework for Surveillance - An integrated Surveillance Decision", July 2012

Jin, K., 2010. International Trade and International Capital Flows: A Theoretical Perspective. In the Encyclopedia of Financial Globalization, New York: Elsevier.

Joyce, J.P., 1992. The economic characteristics of IMF program countries. Economics Letters, vol. 38(2). Elsevier, pp. 237-242.

Knight, M., and Santaella, J., 1997. Economic Determinants of IMF Financial Arrangements. Journal of Development Economics, Vol. 54 (December), pp. 405-36.

Minoiu, C., Kang, C., Subrahmanian, VS., and Berea, A., 2013. Does Financial Connectedness Predict Crises? IMF Working Paper, WP/13/267.

Pesaran M H and Shin Y, 1999. An Autoregressive Distributed Lag Modelling Approach to Cointegration Analysis' in S Strom, (ed.), Econometrics and Economic Theory in the 20th Century: The Ragnar Frisch Centennial Symposium, Cambridge: Cambridge U P. 
Pesaran M H, Shin Y, and Smith R J, 2001. Bounds Testing Approaches to the Analysis of Level Relationships. Journal of Applied Econometrics, 16, 289-326.

Przeworski, A., and Vreeland, J., 2000. The Effect of IMF Programs on Economic Growth. Journal of Development Economics, Vol. 62 (August), pp. 385-421.

Rey, H., 2015. Dilemma not trilemma: The Global Financial Cycle and Monetary Policy Independence. NBER working paper WP21162, May 2015

Reynaud, J., and Vauday, J., 2009. Geopolitics and international organizations: An empirical study on IMF facilities. Journal of Development Economics 89, pp.139-162

Schularick, Moritz and Alan M. Taylor, 2012. Credit Booms Gone Bust: Monetary Policy, Leverage Cycles, and Financial Crises, 1870-2008. American Economic Review 102, 102961.

Sturm J.-A., Berger, H., and De Haan, J., 2005, Which variables explain decisions on IMF credit? An extreme bounds analysis. Economics and Politics, 17 (2), 177-214.

Vreeland, J., 2004. 'Institutional Determinants of IMF Agreements. Global Fellows Working Paper (Los Angeles, UCLA International Institute). 


\section{ANNEX I - LONG TERM RELATIONSHIP BETWEEN GRA CREDIT OUTSTANDING AND THE VIX}

We adopt the ARDL approach to the estimation of the level relations discussed in Pesaran and Shin (1999). Note that this approach is applicable irrespective of whether the regressors are purely I(0), purely I(1) or mutually cointegrated. The estimated orders of an ARDL (p, q) model in the two variables GRA and VIX were selected searching across the all the ARDL models using various AIC criteria (AIC, SC, log likelihood). This resulted in the choice of an ARDL $(2,2)$ model, that can be simplified accordingly to the parsimony principle to the following:

\section{Table I.1. Regression results (without GDP)}

\begin{tabular}{lrrrr}
\hline Variable & Coefficient & Std. Error & t-Statistic & p-value \\
\hline C & 0.25278 & 0.20561 & 1.22945 & 0.222 \\
GRA(-1) & -0.05738 & 0.01684 & -3.40710 & 0.001 \\
VIX(-1) & $\mathbf{0 . 1 2 0 7 1}$ & $\mathbf{0 . 0 3 7 3 2}$ & $\mathbf{3 . 2 3 4 3 0}$ & 0.002 \\
DGRA(-2) & 0.54351 & 0.08883 & 6.11884 & 0.000 \\
DVIX(-2) & -0.15092 & 0.05946 & -2.53837 & 0.013 \\
\hline R-squared & 0.45 & & \\
\hline Note: Parsimonious ARDL (2,2) model. Dependant variable is the difference in \\
GRA credit outstanding. All variables enter the equation in LOG. Estimation \\
period is 1990Q4 to 2014Q4
\end{tabular}

The above p-values are not accurate as the t-statistic distribution are skewed. But Pesaran and others (2001) show that the t-statistic must be higher than 2.60 (no intercept/no trend) or 3.22 (intercept but no trend) to show significance at the $5 \%$ level (see table CII for $\mathrm{k}=1$ ), which is the case here.

Figure I.1. GRA Credit Outstanding Actual and Fitted by ARDL Model (without GDP) (in SDR millions)

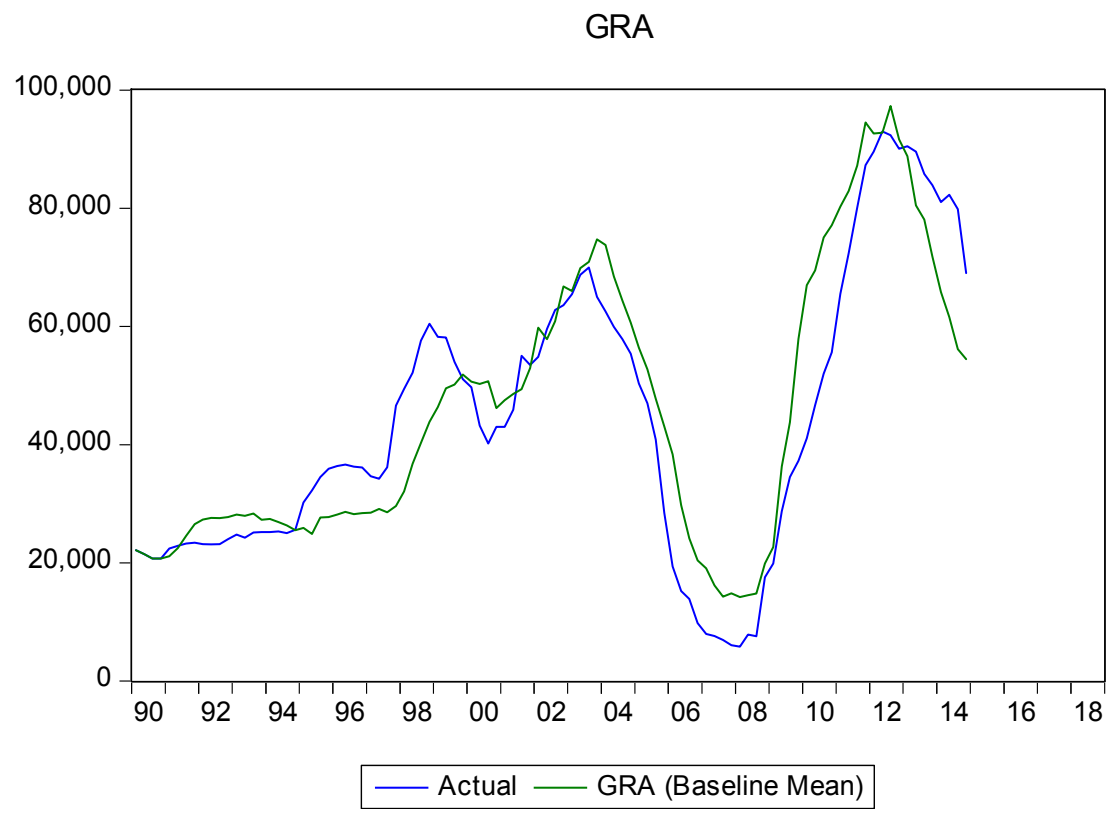


If we add global GDP, there is no significant level relationship with GRA, but GDP variations useful to explain short term dynamics. The level relationship between GRA and VIX still hold (per Pesaran, the t-statistics are now 3.02 and 3.53 at the 5\% level).

Table I.2. Regression results (with GDP)

\begin{tabular}{crrrr}
\hline Variable & Coefficient & Std. Error & t-Statistic & p-value \\
\hline C & 0.92865 & 0.25813 & 3.59758 & 0.001 \\
GRA(-1) & -0.14199 & 0.02585 & -5.49357 & 0.000 \\
VIX(-1) & $\mathbf{0 . 1 7 7 9 2}$ & $\mathbf{0 . 0 4 5 4 2}$ & $\mathbf{3 . 9 1 7 5 6}$ & 0.000 \\
DGRA(-2) & 0.43979 & 0.16666 & 2.63879 & 0.011 \\
DGRA(-3) & 0.36383 & 0.18181 & 2.00111 & 0.050 \\
DGRA(-4) & 0.47815 & 0.18328 & 2.60889 & 0.011 \\
DVIX(-2) & -0.26024 & 0.07946 & -3.27493 & 0.002 \\
DGDP(-1) & -13.75973 & 5.57303 & -2.46899 & 0.016 \\
DGDP(-3) & 18.51124 & 5.81424 & 3.18378 & 0.002 \\
\hline R-squared & 0.62 & & & \\
\hline
\end{tabular}

Figure I.2. GRA Credit Outstanding Actual and Fitted by ARDL Model (with GDP) (in SDR millions)

GRA

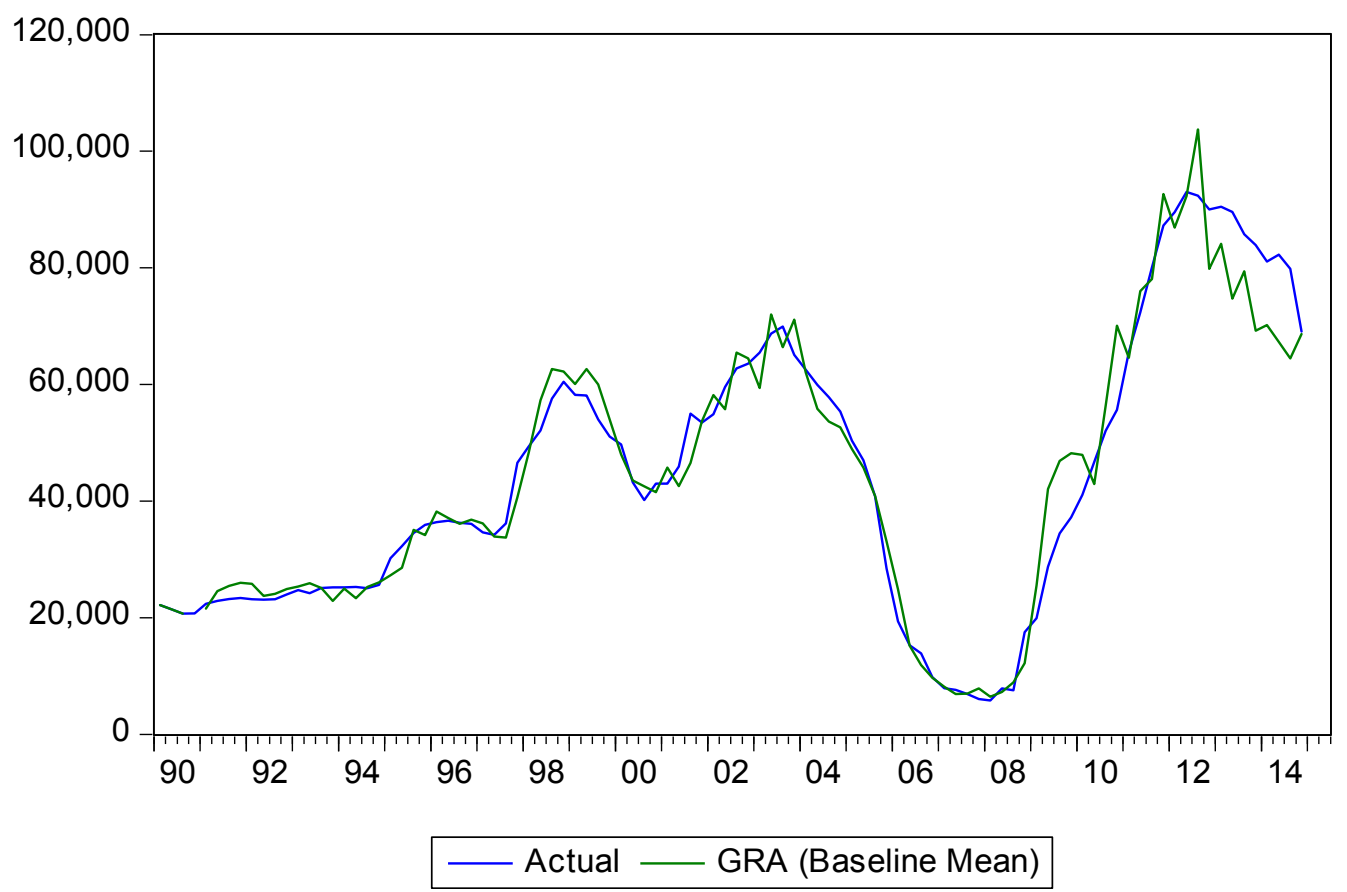




\section{Annex II - Data}

\section{A. Sources}

\begin{tabular}{|c|c|c|}
\hline Variable & Data Source & $\begin{array}{l}\text { Definition } \\
\end{array}$ \\
\hline Past program & IMF & $\begin{array}{l}5 \text {-year average of a dummy that takes the value } 1 \\
\text { when a member has an active IMF arrangement }\end{array}$ \\
\hline External Financing Needs & WEO & See IMF (2010b); ratio (divided by GDP) \\
\hline GDP growth & WEO & in percent \\
\hline GDP per capita & WEO & $\log$ of level in USD \\
\hline GDP & WEO & $\log$ of level in USD billion \\
\hline Credit-to-GDP Gap & BIS; WDI; WEO & deviation of credit-to-GDP from its 6-year average \\
\hline Exchange rate variation & WEO & $\begin{array}{l}\text { variation of bilateral nominal exchange rate against } \\
\text { the US dollar over past } 12 \text { months }\end{array}$ \\
\hline Government Stability & ICRG & $\begin{array}{l}\text { A measure of both of the government's ability to } \\
\text { carry out its declared program, and its ability to } \\
\text { stay in office. The risk rating assigned is the sum of } \\
\text { three subcomponents: Government Unity, } \\
\text { Legislative Strength, and Popular Support. }\end{array}$ \\
\hline Potential Contagion & WEO; DOTS & See main text \\
\hline 3-month US rate & WEO & in percentage points \\
\hline VIX & CBOE & \\
\hline Oil Price & WEO & $\begin{array}{l}\text { difference between oil prices and their past } \\
\text { 5-year average }\end{array}$ \\
\hline
\end{tabular}




\section{B. Interconnectedness indicators' panel summary statistics}

\begin{tabular}{|c|c|c|c|c|c|}
\hline \multicolumn{2}{|c|}{ Interconnectedness indicator } & \multirow{2}{*}{$\frac{\text { Mean }}{0.0074}$} & \multirow{2}{*}{$\frac{\text { Std. dev. }}{0.0155}$} & \multirow{2}{*}{$\frac{\text { Min }}{0}$} & \multirow{2}{*}{$\frac{\operatorname{Max}}{0.1531}$} \\
\hline External financing needs & Overall & & & & \\
\hline & Between & & 0.0114 & 0 & 0.0739 \\
\hline & Within & & 0.0100 & -0.0543 & 0.0866 \\
\hline \multirow[t]{3}{*}{ GDP per capita } & Overall & 1.6511 & 3.0734 & 0 & 26.8542 \\
\hline & Between & & 2.4356 & 0 & 14.5826 \\
\hline & Within & & 1.6810 & -8.2447 & 16.7896 \\
\hline \multirow[t]{3}{*}{ GDP growth } & Overall & 0.5120 & 1.0769 & -4.7113 & 9.8314 \\
\hline & Between & & 0.7463 & 0 & 3.9256 \\
\hline & Within & & 0.7326 & -7.8268 & 6.7192 \\
\hline \multirow[t]{3}{*}{ GDP } & Overall & 1.1337 & 2.0931 & 0 & 18.5431 \\
\hline & Between & & 1.6380 & 0 & 9.4762 \\
\hline & Within & & 1.1820 & -5.7034 & 11.5910 \\
\hline \multirow[t]{3}{*}{ Credit gap } & Overall & 0.0934 & 0.2886 & -0.8679 & 3.5359 \\
\hline & Between & & 0.1375 & 0 & 0.6903 \\
\hline & Within & & 0.2527 & -1.4648 & 2.9390 \\
\hline \multirow[t]{3}{*}{ Exchange rate variation } & Overall & -0.0016 & 0.0247 & -0.2749 & 0.1904 \\
\hline & Between & & 0.0030 & -0.0233 & 0.0003 \\
\hline & Within & & 0.0245 & -0.2637 & 0.2016 \\
\hline \multirow[t]{3}{*}{ Government stability } & Overall & 1.3628 & 2.4168 & 0 & 19.6785 \\
\hline & Between & & 1.9794 & 0 & 11.6112 \\
\hline & Within & & 1.2095 & -6.6822 & 11.7563 \\
\hline \multirow[t]{3}{*}{ PCA of potentials } & Overall & 0.5098 & 1.0751 & -4.7113 & 9.8314 \\
\hline & Between & & 0.7437 & 0 & 3.9256 \\
\hline & Within & & 0.7310 & -7.8290 & 6.7170 \\
\hline
\end{tabular}




\section{Countries in the sample}

Albania
Algeria
Angola
Argentina
Armenia
Australia
Austria
Azerbaijan
Bahamas, The
Bahrain
Belarus
Belgium
Botswana
Brazil
Canada
China
Colombia
Costa Rica
Croatia
Cyprus
Czech Republic
Denmark
Dominican Republic

Ecuador
Egypt
El Salvador
Estonia
Finland
France
Gabon
Germany
Greece
Guatemala
Guyana
Hungary
Iceland
India
Indonesia
Iran
Iraq
Ireland
Israel
Italy
Jamaica
Japan
Jordan

Kazakhstan

Korea

Kuwait

Latvia

Lebanon

Libya

Luxembourg

Malaysia

Malta

Mexico

Morocco

Namibia

Netherlands

New Zealand

Norway

Oman

Pakistan

Panama

Peru

Philippines

Poland

Portugal

Qatar

Romania
Russia
Saudi Arabia
Singapore
Slovak Republic
Slovenia
South Africa
Spain
Sri Lanka
Suriname
Sweden
Switzerland
Syria
Thailand
Trinidad and Tobago
Tunisia
Turkey
Ukraine
United Arab Emirates
United Kingdom
Uruguay
Venezuela

Russia

audi Arabia

Slovenia

outh Africa

Spain

Sri Lanka

Suriname

Sweden

witzerland

ad and Tobago

isia

key 